\title{
THE ECONOMETRIC THEORY AWARDS
}

In the natural sciences and the humanities, professional associations and national and international organizations offer many awards to recognize the accomplishments of scientists and writers. The economics profession, however, offers relatively few awards to acknowledge and reward the scientific work of its large community of scholars. The situation is particularly severe in econometrics, where the paucity of awards stands in contrast to the enormous growth of this part of the discipline in recent years.

Some years age, Econometric Theory took a step forward in remedying this imbalance by instituting the Tjalling $\mathrm{C}$. Koopmans Econometric Theory Prize. Since 1987, this prize has been awarded every three years to the author or authors of the article published in the journal over the preceding three years that is selected by the Advisory Editors of the Journal as the most deserving piece of scientific work published in that period. The Koopmans Prize carries a financial reward of $\$ 1,000$ and is jointly supported by Cambridge University Press and Mrs. Truus Koopmans. By its very nature, this prize is discretionary and the system of selection relies intimately on the judgment of the journal's advisory editors and their personal assessments of the relative merits of a large number of potential candidate papers. This system of selection is especially appropriate because the award carries a coveted title that honors the memory of Tjalling Koopmans and his own distinguished contributions to the subject of econometrics. In establishing this prize, I wanted to be sure that the winning articles were indeed worthy of the title Koopmans Prize and this required independent assessment by senior scientists in the field.

In addition to this very special award in econometric theory, I believe that there is a need to recognize authors who have moved the subject forward by virtue of their cumulative contributions and sustained publishing efforts over a period of years. It is this type of contribution that has helped econometrics grow into the huge subject area in economics that it is today, and it has helped a large number of individual econometric fields grow to maturity, especially in the last decade. It seems to me to be especially important that young scholars be encouraged in their pursuit of excellence and research recognition by the knowledge that continued, long-term efforts in research will be acknowledged.

Accordingly, I am delighted to announce the institution by this Journal of a new series of awards to be known as the Econometric Theory Awards. There will be three ranks of award. The awards will be given on the basis of an author's sustained publishing effort in the journal Econometric Theory. The criteria to be used will be automatic and will be based on a point system 
whereby a sole-authored article in $E T$ will count as 2 points and a co-authored article in $E T$ will count as 1 point. Points will accumulate annually from the inception of the Journal in 1985. The award criteria will be as follows:

Econometric Theory Multa Scripsit Award for at least 5 points.

Econometric Theory Plura Scripsit Award for at least 10 points.

Econometric Theory Plurima Scripsit Award for at least 20 points.

The awards will be made annually, as soon as an author publishes the requisite number of articles. Having received the award Multa Scripsit (literally, "he has written many"), an author becomes a candidate for the Plura Scripsit award and, thereafter, the award Plurima Scripsit.

The awards will be accompanied by an announcement in the journal and authors will be presented with a certificate that bears their name, the year, the Editor's signature, and the appropriate Latin inscription in the ribbon that underscores the Econometric Theory shield - for example, Opera Econ-ometrica Multa Scripsit ("he/she has written many scientific works in econometrics"). A copy of the award certificate with the new Econometric Theory shield is given on the accompanying page.

I am pleased to announce the following Econometric Theory Awards for 1997.

Multa Scripsit-K. Abadir, A.R. Bergstrom, H. Bierens, Y. Chikuse, I. Choi, C. Gourieroux, B. Hansen, J. Hidalgo, G. Hillier, J. Knight, L.-F. Lee, H. Lutkepohl, K. Maekawa, J. Magnus, A. Monfort, W. Newey, P. Perron, B. Potscher, C. Skeels, K. Tanaka, H. White, and J. Wooldridge.

Plura Scripsit-D.W.K. Andrews, P.C.B. Phillips, and P. Saikkonen.

Peter C.B. Phillips Madison, Connecticut October 1996 


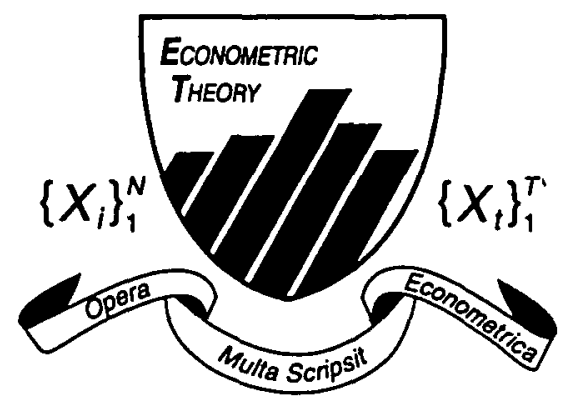

\section{Econometric Theory Award}

\section{In Recognition of Research Contributions, multa scripsit, to the Science of Econometrics}

Peter C. B. Phillips, Editor Econometric Theory 